TITLE:

\title{
Swirl and Combustion in Divided Combustion Chamber Type Diesel Engines(Abstract_要旨)
}

$\operatorname{AUTHOR}(S):$

Kakimoto, Harutoshi

\section{CITATION:}

Kakimoto, Harutoshi. Swirl and Combustion in Divided Combustion Chamber Type Diesel Engines. 京都大学, 1960, 工学博士

\section{ISSUE DATE:}

1960-03-23

URL:

http://hdl.handle.net/2433/210704

RIGHT: 


\section{【58】}
氏 名
柿本治利
学位の種 類
工学 博士
学位記番号
工. 博 第 24 号
学位授与の日付
昭和 35 年 3 月 23 日
学位授与の要件
学位. 規則第 5 条第 1 項該当
研究科・専攻
工学研究科機械工学専攻
学位論文題目

\section{Swirl and Combustion in Divided Combustion Chamber Type Diesel Engines}

（副室式ディーゼル機関に括ける渦流と燃焼）

(主 查)

論文調查委員教 授 長尾不二夫 教 授 佐藤 俊 教 授 森 美 郎

\section{論 交内容の 要旨}

この論文は，副室式ディーゼル機関における渦流と混合気形成ならびに燃焼との関係について研究した 結果をまとめたものであって，緒言，本交 4 章拉よび結論からなっている。

緒言には，ての研究の目的および概要を述べ，高速ディーゼル機関の混合気形成㧍よび燃焼の促進には 架気流動が重要な役割を果しているにかかわらず，従来この方面の研究はふじゆふぶんであり，特に渦流 発生の時期に関しては，全く考慮されていないことを指摘している。

第 1 章では，副室式ディーゼル機関の燃燒に関する基礎的な問題を取り扱っている。

第 1 節は副窒機関の設計上，根本問題とされている燃燒渦流の強さおよびその発生の時期，ならびに渦 流と燃料噴射方向との関係について研究した結果である。著者は主副両室に噴射弁を有する耐熱ガラス空 付きの特殊な燃焼室を用いて, 種々の条件のもとに運転し, 渦流と燃焼との関係を, 高速写真, 排気濃度, 最高圧力，压力上昇率，燃焼音括よび機関性能の諸点から検討し，渦流による燃焼改善の方針を具体的に 示し, 特に燃料の着火後に与えられた渦流は, 最高圧力, 压力上昇率, 燃焼音および排気濃度を低下せし め, 燃焼改善に有効なととを強調している。

第 2 節に扔いては, 従来顧みられなかった予燃燒室内の着火位置が燃焼に関係あることに注目し, 罗当 な仮定のもとに，円筒形予燃㶹室に括ける炎伝播，压力上昇招よび噴出エネルギを各着火位置に対して理 論的に計算し，着火位置により燃焼時間抢よび噴出エネルギに著しい相違があることを見出し，かつ，噴 出エネルギが最大となる着火位置を求め，さらに，模型実験により上記の理論を立証するとともに，各種 形状の燃焼室について，噴射エネルギが最大となる着火位置を見出している。

第 2 章は子燃焼室機関における洞流と燃焼との関係について研究したものである。

第1節に抢いては，予燃焼室内の部分的燃焼により，未燃焼部分が主燃焼室へ一度に噴出されないた め，燃焼が 2 段に行なわれ，燃燒が遅延することを，圧力曲線および炎の高速写真により明らかにし，乙 れが効率低下の一原因であることを指摘し，乙れを改善するため，第 1 章第 2 節に記載の理論にしたがい， 


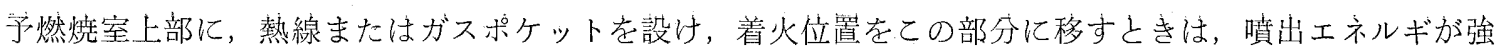
化され, かつ, 未燃燒部分が早期に噴出されるため, 燃焼時間は短縮され, 性能が著しく改善されること を実用機関により立証し，その燃焼経過在王力線図により詳細に説明している。

第 2 節では，予燃焼室の形状，噴霧角，流入気流の力向ならびに噴気孔の形状による混合気形成抢上び 炎の発達の相違を高速写真により検討し，さらに，実用機関により性能との関係を明らかにし，予燃燒室 機関の性能改善には，噴霧と流入気流の正面衝突をさけ，また，貫徽力の大きいノズルを用い，燃料を噴 気孔付近に集中せしめ，すみやかに主燃狫室への噴出をはかり，予燃烧室内では空気過剘の状態で然烧さ すべきであり，強い渦流は燃料の主燃狫室への噴出を妨害すると結論している。

第 3 節では，主燃焼室にお㧍ける焱の発達を高速撮影し，予燃焼室からのガス噴出之炎の拡がり，ならび に燃焼渦流との関係について考察し，さらに，噴気孔の数拉よび方向と炎の拡がりとの関係，ピストン凹 みの効果，ピストン頭への衝突の影響ならびに間隙内における炎の掋がりなどを，高速写真により明らか にするとともに，実用機関により性能との関係を求め，主燃烧室内の筀気利用率增進に関して具体的な方 法を示している。

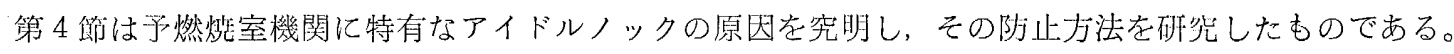

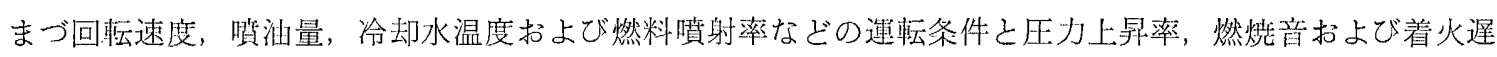
れとの関係を求め, アイドルノックの発生が着火㩧れのみでは説明できないととを指摘し，特殊の燃烧室 を用い，各種の貲気孔あるいは噴射方法によりノックの原因を追及し，主副両窒の圧力曲線を詳細に検討 した結果，アイドルノックは主燃燃室内で発生され，その原因は燃料が主燃烧室へ素通りするてとに基づ くと言う新しい見解を与えた。さらに，光電管および高速写真により，主副雨室の炎の発生状況を比較 し，著者の見解を確認し，なお，とれに基づきアイドルノック防止に対する具体的方法を述べ，ピント一 ノズルが最む効果的であるととを強調している。

第 3 章は渦流室機関における渦流と燃焼との関係について研㶢したものである。

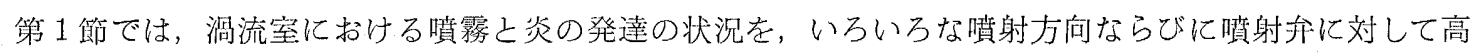
速撮影し，機関性能招よび排気濃度とあわせて検討し，気流に載せて噴射するときは，炎は佩巻状に中心 に巻き込まれ，外周の濃混合気の部分から順次主燃燒室に排出され，無煙燃燒が行われるが，中心または 渦流と反対方向の噴射では，炎は中心部に塊状に集結し，外周の空気の部分から主燃焼室に排出されるた め，渦流室は空気不足の状態となり，多量の煤を発生し，性能が低下するという重要な事実を見出してい る。しかしながら，平底渦流室に扣いては渦流がすみやかに減衰されるため，噴射方向の影響は円形洞流 室に㧍けるほど鋭敏でないととを述べている。

第 2 節では，渦流の強さの影響を高速写真ならびに機関性能に基づき検討し，円形渦流室では連絡孔面 積を小さくし，渦流速度を高くすると，燃燒は改善されるが，平底燃焼室ではほとんどその効果はなく， 性能は低下するてとを見出している。

第 3 節では, 渦流室の軸方向における炎の発達状況を高速撮影し, 着火後の混合気形成状沉について論 じ，第 4 節では，主燃焼公内の炎写真および性能試験の結果により，ピストン凹みの効果を検討し，第 5 節には，以上の結果を総合して渦流室機関の燃跳改善の力法を述べている。 
第 4 章はラノバ型空気室機関における珮流之燃焼との関係について研究したものである。

第 1 節では，まず，空気室からの噴出エネルギは，空気室扔よび噴気孔の寸法によるほか，空気室に流 入する燃料の量に関係することを述べ，性能試験により，最適の空気室および噴気孔の形状・寸法ならび に噴射条件を決定し，ついで，高速写真により，渦流発生の状況ならびに噴射時期により着火位置が変動 する様子を明らかにし，かつ，それに伴ない圧力上昇に著しい相違を生ずることを認めた。

第 2 節では, 熱線により着火位置を変えて, 性能試験を行い, 主燃焼室内の着火が架気室と同時または 早く起こる場合に良好な性能が得られることを確かめ, ラノバ型空気室機関では噴霧角の小さいノズルを 用い，空気室への流入燃料を多くし，同時に主燃焼室内の混合気形成を抑制し，着火後空気空からのガス 噴出により，混合気形成を助長することが静肃な運転と高性能を得る方法であると結論している。

結論は以上の研究結果を総括したものである。

\section{論 交 審 查 の 結 果 の 要 旨}

この論文は, 副窒ディーゼル機関の高速化に最も重要とされている渦流による混合気形成掞よび燃焼の 促進に関する研究をまとめたもので, 従来困難とされていた実験の機関内における燃料噴霧打よび燃焼火 炎の高速撮影に成功し，従来推定に過ぎなかった燃焼公内の混合気分布ならびに燃焼経過を明らかにする とともに，渦流と燃料噴射方向および渦流発生の時期に関して，新しい多くの事実を発見し，乙れにもと

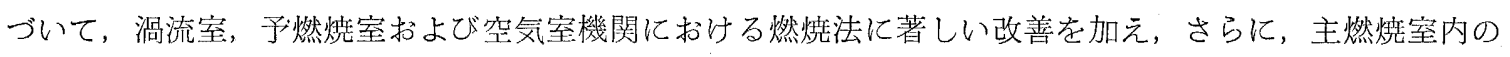
空気利用に関してあ，噴気孔およびピストン凹みに対して，設計上の有益な資料を提供している。また， 予燃焼室内における着火位置が未燃焼燃料の噴出量および噴出エネルギに大きな影響を及ぼすととを理論 的計算により見出し，乙れを応用して予燃燒室機関の性能向上をはかり，なお，予燃焼室機関のアイドル ノックに関して, 新しい知見を加え, その除去に有效な方法を見出している。このように, 本研究は学術 上にも工業上にも貢献するところが少なくない。よって, 本論文は工学博士の学位論文として価値あるも のと認める。

〔主論文公表誌〕

第 1 章 日本機械学会論文集 第25巻 (昭. 34) 第160号

日本機械学会論文集 第24巻 (昭. 33) 第140号

第 2 章 日本機械学会論文集 第23巻 (昭. 32) 第132号

MTZ, Jg.18 (1957), Nr.10

Memoirs of the Faculty of Engineering, Kyoto University, Vol.20 (1958), No. 1

日本機械学会論交集 第24巻 (昭. 33) 第144号

Bulletin of JSME, Vol. 2 (1959), No. 5

日本機械学会論文集 第26巻 (昭. 35) 第162号

第 3 章 日本機械学会論文集 第25巻 (昭. 34) 第160号

MTZ, Jg.20 (1959), Nr. 6

Memoirs of the Faculty of Engineering, Kyoto University, Vol.22 (1960), No. 1

第 4 章 日本機械学会論文集 第23巻（昭. 35）第162号

〔参 考 墖 交〕 